\title{
Tata Laksana Non Imunosupresan Sindrom Nefrotik pada Anak
}

\author{
Sudung O. Pardede \\ Departemen Ilmu Kesehatan Anak Fakultas Kedokteran Universitas Indonesia-RS Dr. Cipto Mangunkusumo, Jakarta
}

\begin{abstract}
Abstrak
Sindrom nefrotik adalah keadaan klinis yang terdiri atas proteinuria masif, hipoalbuminemia $(<2,5 \mathrm{~g} / \mathrm{dL})$, edema, dan hiperkolesterolemia. Terapi utama sindrom nefrotik adalah imunosupresan terutama kortikosteroid. Pada sindrom nefrotik relaps sering atau dependen steroid, dan sindrom nefrotik resisten steroid, selain steroid diberikan juga imunosupresan lain. Selain pemberian imunosupresan diperlukan terapi suportif, yang meliputi terapi diitetik, tata laksana edema, hipertensi, hipovolemia, trombosis, hiperlipidemia, dan infeksi. Tata laksana diitetik terdiri atas kalori yang adekuat, protein sesuai recommended daily allowance, lemak low saturated, dan rendah garam. Komposisi zat gizi yang dianjurkan terdiri atas 10\%-14\% protein; 40\%-50\% lemak poly- dan monounsaturated, 40\%-50\% karbohidrat. Tata laksana edema terdiri atas restriksi cairan, pemberian diuretik, dan infus albumin jika perlu. Infeksi yang sering terjadi pada sindrom nefrotik adalah selulitis peritonitis, dan pneumonia yang diterapi dengan antibiotik sefotaksim, seftriakson, ko-amoksiklav. Antihipertensi yang digunakan pada anak umumnya diuretik, angiotensin converting enzyme inhibitors, angiotensin receptor blockers, calcium channel blockers, alpha-symphatetic agents, beta blockers dan vasodilator. Aktivitas fisik tidak perlu dibatasi, dan pada edema ringan atau tidak berat tidak perlu dilarang pergi ke sekolah. Sari Pediatri 2017;19(1):53-62
\end{abstract}

Kata kunci: anak, sindrom nefrotik, terapi suportif

\section{Management of Non Immunosuppressant Nephrotic Syndrome in Children}

Sudung O. Pardede

\begin{abstract}
Nephrotic syndrome is clinical condition consists of massive proteinuria, hypoalbuminemia $(<2,5 \mathrm{~g} / \mathrm{dL})$, oedema, and hypercholesterolemia. The main treatment of nephrotic syndrome is steroid. In some conditions, besides steroid, it is used other immunosuppressant. Besides immunosuppressant, supportive management is very important in treatment of nephrotic syndrome, such as dietetic, management of oedema, hypertension, hypovolemia, trombosis, hyperlipidemia, and infection. Dietetic management consist of adequate of calorie, protein according to recommended daily allowance, low saturated, lipid, and salt restriction diet. The compostion of nutrition is $10-14 \%$ of protein; $40-50 \%$ of poly- and monounsaturated, lipid and $40-50 \%$ of carbohydrate. Treatment of oedema consists of ata fluid restriction, diuretics, and albumin infusion if needed. Infection is often happened in nephrotic syndrome, such as selulitis, peritonitis, and pneumonia which treated with antibiotics cefotaxime, ceftriaxonen, co-amoxyclav. Antihypertension for children usually are diuretics, angiotensin converting enzyme inhibitors, angiotensin receptor blockers, calcium channel blockers, alpha-symphatetic agents, beta blockers and vasodilator. Physical activity limitation is unnecessary and the child with mild or not severe oedema allowed go to school. Sari Pediatri 2017;19(1):53-62
\end{abstract}

Keywords: children, nephrotic syndrome, supportive management

Alamat korespondensi: DR. Dr. Sudung O. Pardede, SpA(K). Departemen Ilmu Kesehatan Anak Fakultas Kedokteran Universitas Indonesia/RS Dr. Cipto Mangunkusumo, Jakarta. E-mail: suopard@yahoo.com 


\section{Pendahuluan}

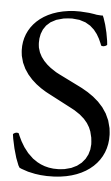

indrom nefrotik adalah keadaan klinis yang terdiri atas proteinuria masif, hipoalbuminemia $(<2,5 \mathrm{~g} / \mathrm{dL})$, edema, dan hiperkolesterolemia. Sindrom nefrotik merupakan penyakit ginjal yang sering pada anak. Terapi utama sindrom nefrotik adalah kortikosteroid, yaitu prednison dosis penuh (full dose) $60 \mathrm{mg} / \mathrm{m}^{2} \mathrm{LPB} /$ hari selama 4 minggu dilanjutkan dengan prednison dosis $2 / 3$ nya $(40 \mathrm{mg} /$ $\mathrm{m}^{2} \mathrm{LPB} /$ hari) tiga hari berturut-turut dalam seminggu (intermitten) atau selang hari (alternating) selama 4 minggu. ${ }^{1-6}$ Secara klinis sindrom nefrotik dapat dibagi menjadi sindrom nefrotik responsif steroid, sindrom nefrotik relaps jarang, sindrom nefrotik relaps sering dan dependen steroid, dan sindrom nefrotik resisten steroid. ${ }^{1-6}$

Pada keadaan tertentu, selain steroid diberikan juga imunosupresan lain seperti siklofosfamid, klorambusil, siklosporin, mikofenolat mofetil, takrolimus, rituximab, atau pun levamisol. Sindrom nefrotik dapat menyebabkan berbagai komplikasi seperti hipovolemia, renjatan, gangguan ginjal akut, infeksi, trombosis, gangguan elektrolit, malnutrisi, dan pertumbuhan terlambat. ${ }^{6-10}$ Selain pemberian kortikosteroid atau imunosupresan, diperlukan tata laksana suportif.

\section{Tata laksana suportif}

Terapi suportif pada sindrom nefrotik meliputi terapi diitetik, tata laksana edema, hipertensi, hipovolemia, trombosis, hiperlipidemia, dan infeksi. Anak dengan manifestasi klinis sindrom nefrotik pertama kali sebaiknya dirawat di rumah sakit untuk mempercepat diagnosis, pengaturan diit, tata laksana edema, edukasi orangtua, dan memulai pemberian steroid. Pasien juga perlu dirawat jika terdapat edema anasarka, syok, gagal ginjal, infeksi berat, hipertensi berat, atau muntahmuntah. ${ }^{11}$

\section{Diit}

Tata laksana diitetik terdiri atas kalori adekuat sesuai umur, protein cukup, lemak low saturated, dan rendah garam, ${ }^{12}$ Komposisi zat gizi yang dianjurkan terdiri atas $10-14 \%$ protein; $40-50 \%$ lemak poly-dan monounsaturated, 40-50\% karbohidrat. ${ }^{8,13}$
Karbohidrat lebih dianjurkan karbohidrat kompleks dibandingkan dengan karbohidrat sederhana, ${ }^{12}$ berupa starch atau dekstrin-maltosa dan hindari pemberian sukrosa yang dapat meningkatkan gangguan lemak. ${ }^{10}$

Pada dekade lalu, sindrom nefrotik ditata laksana dengan diit tinggi protein untuk mengatasi hipoalbuminemia, namun tidak ada bukti yang menyebutkan asupan tinggi protein dapat memperbaiki kadar albumin. Diit tinggi protein tidak dianjurkan lagi, bahkan merupakan indikasi kontra karena akan menambah beban glomerulus untuk mengeluarkan sisa metabolisme protein pada saat filtrasi (hiperfiltrasi), yang menyebabkan sklerosis glomerulus. ${ }^{13}$ Sebaliknya, diit rendah protein akan menyebabkan malnutrisi protein dan hambatan pertumbuhan anak. ${ }^{11}$ Sekarang ini, sindrom nefrotik ditata laksana dengan diit protein normal sesuai dengan recommended daily allowance $(\mathrm{RDA})^{11}$ atau $130-140 \% \mathrm{RDA},{ }^{10}$ yaitu 1,5-2 g/kgbb/ hari. ${ }^{11}$ dan dianjurkan protein high-biologic value. ${ }^{12,13}$ Pasien dengan proteinuria persisten atau berulang perlu meningkatkan asupan protein harian menjadi 2-,2,5 $\mathrm{g} / \mathrm{kgbb} /$ hari. $^{10}$

Lemak tidak lebih dari $30 \%$ total kalori ${ }^{12,14}$ dan hindari lemak jenuh karena akan memperburuk hiperlipidemia. $^{8}$

Restriksi garam diperlukan jika terdapat edema, relaps, atau hipertensi yang bertujuan untuk mencegah dan mengobati edema dan hipertensi, ${ }^{6}$ dengan diit rendah garam (1-2 g/hari atau $1 \mathrm{mmol} / \mathrm{kgbb} / \mathrm{hari}$ atau $<2 \mathrm{mEq} / \mathrm{kgbb} / \mathrm{hari}$ ) dengan membatasi asupan snack atau makanan mengandung garam, ${ }^{10,11}$ seperti sup, pickles, dan kentang goreng. Perlu diketahui bahwa garam $\mathrm{NaCl}$ terdiri atas $40 \%$ natrium dan $60 \%$ klorida. Satu sendok teh garam $\mathrm{NaCl}$ sama dengan 6 gram $\mathrm{NaCl}$ atau $2400 \mathrm{mg}$ natrium. atau $1 \mathrm{gram} \mathrm{NaCl}$ mengandung $400 \mathrm{mg}$ natrium dan 1 gram $\mathrm{NaCl}$ mengandung 17,1 mmol natrium atau $1 \mathrm{mmol} \mathrm{NaCl}$ sama dengan 23 mg natrium. Pada kebanyakan kasus sindrom nefrotik sensitif steroid, tidak diperlukan restriksi garam dan cairan. ${ }^{12}$

Umumnya asupan air tidak perlu dibatasi, dapat diberikan hingga 1,5 kali kebutuhan, kecuali pada edema berat. ${ }^{10,12}$ Restriksi cairan diperlukan pada penurunan fungsi ginjal (cairan diberikan sesuai insensible water loss dan jumlah urin per hari), ${ }^{12}$ edema berat (restriksi cairan hingga 50\% kebutuhan rumatan), ${ }^{13}$ dan hiponatremia sedang hingga berat (kadar $\mathrm{Na}<125 \mathrm{mEq} / \mathrm{L}){ }^{10}$ 


\section{Edema}

Tata laksana edema terdiri atas restriksi cairan, restriksi garam, dan diuretik. ${ }^{8}$ Diperlukan pemantauan penurunan berat badan untuk menilai efektivitas tata laksana. ${ }^{15}$

Sebagian besar sindrom nefrotik sensitif steroid tidak memerlukan terapi spesifik untuk edema. Pada edema ringan, tata laksana biasanya bersifat konservatif dengan restriksi cairan hingga dua pertiga kebutuhan rumatan dan diit rendah garam. Pemberian kortikosteroid sendiri dapat meningkatkan diuresis dalam 2-4 hari.

Sindrom nefrotik yang memerlukan diuretik adalah sindrom nefrotik dengan edema, hipertensi, atau peningkatan berat badan bermakna. Pada penggunaan diuretik perlu dipertimbangkan apakah edema berupa underfill (volume intravaskular berkurang) atau overfill (retensi natrium renal primer). Keadaan ini sering sulit dibedakan, tetapi ada panduan untuk membedakannya. Dicurigai sebagai edema underfill jika terdapat hipotensi postural, riwayat sindrom nefrotik kelainan minimal, kadar albumin serum < $2,0 \mathrm{~g} / \mathrm{dL}$, dan laju filtrasi glomerulus estimasi $>75 \%$. Diperkirakan sebagai overfill jika terdapat hipertensi, kadar albumin serum $>2,0 \mathrm{~g} / \mathrm{dL}$, dan laju filtrasi glomerulus estimasi $<50 \% .^{15}$

Pemberian diuretik pada edema underfill memerlukan pemantauan hemodinamik sistemik dan fungsi ginjal untuk meyakinkan tidak terjadi penurunan volume intravaskular, dan biasanya dimulai dengan diuretik dosis rendah. ${ }^{15}$ Pada edema overfill, perlu pemberian diuretik yang agresif, biasanya loop diuretic yang mempunyai durasi singkat, biasanya 6 jam sehingga diberikan minimal dua kali sehari. Penelitian membuktikan bahwa furosemid $1 \mathrm{mg} / \mathrm{kgbb}$ secara intravena dua kali lebih efektif dibandingkan furosemid $2 \mathrm{mg} / \mathrm{kgbb}$ secara oral. Jika diberikan kombinasi loop diuretic dengan thiazide atau loop dengan thiazide like (metolazone), perlu pemantauan untuk menghindari hipokalemia atau alkalosis. Penambahan amilorid atau mineralocorticoid-receptor-antagonist (spironolakton) terhadap pemberian loop diuretic dapat meminimaliser hipokalemia. ${ }^{15}$ Diuretik yang sering digunakan adalah furosemid, loop diuretics yang menghambat transpor sodium-potassium-2 chloride di thick ascending limb of loop of Henle. ${ }^{16}$

Pemberian infus albumin harus hati-hati. Infus albumin lebih bermanfaat pada keadaan edema underfill terutama jika kadar albumin $<2,0 \mathrm{~g} / \mathrm{dL}$. Efek albumin hanya sementara, dan jika diperlukan infus albumin dapat diulang. ${ }^{6,15,16}$ Pasien dengan edema berat terutama edema skrotum atau labia, asites atau efusi pleura terindikasi pemberian infus albumin. ${ }^{6}$ Infus albumin 20-25\% diberikan dengan dosis $1 \mathrm{~g} /$ kgbb selama 3-4 jam diikuti pemberian furosemid intravena $1-2 \mathrm{mg} / \mathrm{kgbb}$ pada pertengahan dan akhir infus albumin. ${ }^{16}$ Pemberian furosemid dengan albumin dapat meningkatkan efektivitas furosemid dengan meningkatkan volume intravaskular, yang memperbaiki perfusi ginjal dan penghantaran obat ke ginjal. Umumnya, peningkatan kadar albumin hingga 2,8 g/dL sudah adekuat untuk memperbaiki volume dan tekanan onkotik intravaskular. ${ }^{10}$

Dapat diberikan furosemid bolus $(1-3 \mathrm{mg} / \mathrm{kgbb} /$ dosis) selama 15-30 menit atau infus terus-menerus dengan dosis $0,1-1 \mathrm{mg} / \mathrm{kgbb} / \mathrm{jam}$ atau dikombinasi dengan spironolakton. ${ }^{16}$

Pada sindrom nefrotik, penambahan thiazide-type diuretics seperti metolazon yang bekerja pada tubulus distal dan tubulus proksimal meningkatkan efektivitas furosemid. Keadaan ini menyebabkan efek sinergi untuk menghambat reabsobsi natrium pada beberapa tempat di nefron. Loop diuretics mempunyai efek samping trombosis, hipokalemia, alkalosis metabolik, hiperkalsiuria, nefrokalsinosis, dan ototoksisitas. ${ }^{8}$ Pada hipoalbuminemia berat $(<1,5 \mathrm{~g} / \mathrm{dL})$ disertai hipovolume, pemberian diuretik tidak efektif dan malah dapat membahayakan. ${ }^{12}$

Pasien yang mendapat diuretik di unit rawat jalan memerlukan evaluasi 48-72 jam kemudian. Diuretik dihentikan jika terjadi pusing dan nyeri abdomen, dan dievaluasi terhadap kemungkinan hipovolemia atau jika anak mengalami muntah, diare, atau asupan per oral sulit. ${ }^{16}$ Hindari pemberian diuretik jangka lama pada pasien rawat jalan. ${ }^{8}$ Parasentesis dapat dilakukan pada asites atau efusi pleura berat yang refrakter, dan dilakukan dengan secara aseptik dan hati-hati ${ }^{6,10,15,16}$

\section{Hipovolemia}

Pasien dengan hipovolemia, ditata laksana dengan infus $\mathrm{NaCl}$ fisiologis atau ringer laktat $15-20 \mathrm{~mL} / \mathrm{kgbb}$ secepatnya atau dalam 20-30 menit, disusul pemberian albumin $1 \mathrm{~g} / \mathrm{kgbb}$ atau plasma $20 \mathrm{~mL} / \mathrm{kgbb}$, diberikan dengan tetesan lambat 10 tetes per menit. Diuretik dihentikan. ${ }^{11}$ Jika masih terdapat hipovolemia, bolus 
$\mathrm{NaCl}$ fisiologis atau ringer laktat dapat diulang. Jika tidak memberikan respon dengan pemberian dua kali bolus cairan $\mathrm{NaCl}$ fisiologis atau ringer laktat, berikan infus albumin $5 \%$ dosis $10-15 \mathrm{~mL} / \mathrm{kgbb}$ atau albumin $20 \%$ dosis $0,5-1 \mathrm{~g} / \mathrm{kgbb} .{ }^{16}$ Bila hipovolemia sudah teratasi dan pasien masih mengalami oliguria, berikan furosemid 1-2 mg/kgbb intravena. ${ }^{11}$

\section{Infeksi}

Sindrom nefotik rentan terhadap infeksi. Pada edema, terdapat peningkatan tekanan hidrostatik di interstitium yang menyebabkan penurunan perfusi interstitium, sehingga mudah mengalami kerusakan kulit dan mengakibatkan infeksi. Infeksi yang sering terjadi pada sindrom nefrotik adalah selulitis, pneumonia, dan peritonitis. Infeksi virus dapat menjadi serius pada sindrom nefrotik yang sedang mendapat kortikosteroid atau imunosupresan lain. ${ }^{8}$

Selulitis diterapi dengan kloksasilin intravena 100$200 \mathrm{mg} / \mathrm{kgbb} / \mathrm{hari}$ atau seftriakson $50-100 \mathrm{mg} / \mathrm{kgbb} /$ hari yang dapat dilanjutkan dengan pemberian oral kloksasilin $(100 \mathrm{mg} / \mathrm{kgbb} / \mathrm{hari})$ atau ko-amoksiklav $30-40 \mathrm{mg} / \mathrm{kgbb} / \mathrm{hari}$ atau sefiksim $8 \mathrm{mg} / \mathrm{kgbb} / \mathrm{hari}$ sehingga lama pemberian antibiotik 10 hari. ${ }^{16}$

Peritonitis ditandai dengan nyeri abdomen, tenderness, diare, muntah, dan pada cairan asites ditemukan $>100$ leukosit $/ \mathrm{mm}^{3}$ atau $>50 \%$ neutrofil dalam cairan asites. ${ }^{16}$ Pengobatan awal peritonitis adalah antibiotik broad spectrum intravena. Hasil biakan negatif dapat terjadi karena jumlah bakteri yang sedikit. Pada beberapa pasien dapat terjadi peritonitis berulang karena faktor risiko host spesifik. Setelah memperoleh hasil biakan, antibiotik pilihan adalah antibiotik spektrum sempit. ${ }^{8}$ Peritonitis diterapi dengan sefotaksim 100-150 mg/kgbb/hari atau seftriakson $75-100 \mathrm{mg} / \mathrm{kgbb} /$ hari selama 7 hari. ${ }^{16}$ Upaya mencegah peritonitis dilakukan dengan imunisasi dan antibiotik profilaksis. ${ }^{8}$

Infeksi virus respiratory syncytial virus (RSV), virus influenza, parainfluenzae, virus varisela-zoster,dan adenovirus sering mencetuskan relaps, sedangkan infeksi virus morbili dapat mencetuskan remisi. ${ }^{15}$

Varisela merupakan infeksi virus yang serius pada sindrom nefrotik idiopatik dan dapat mengancam jiwa terutama bagi anak yang mendapat kortikosteroid atau imunosupresan lainnya. ${ }^{8,15}$ Pasien perlu menghindari kontak dengan penderita varisela. Bila terjadi kontak, untuk mencegah timbulnya varisela, dapat diberikan imunoglobulin varisela-zoster intravena $125 \mathrm{IU} / 10 \mathrm{~kg}$ atau $400 \mathrm{mg} / \mathrm{kgbb}$ dosis tunggal dalam 96 jam setelah terpapar atau asiklovir sebagai pencegahan. ${ }^{8,11,13,16}$ Bila sudah terjadi infeksi, pasien diterapi dengan asiklovir intravena $1,500 \mathrm{mg} / \mathrm{m}^{2} \mathrm{LPB} /$ hari dibagi 3 dosis atau asiklovir oral $80 \mathrm{mg} / \mathrm{kgbb} / \mathrm{hari}$ dibagi 4 dosis selama 7-10 hari, dan pemberian steroid dihentikan untuk sementara, ${ }^{11,16,17}$ atau diturunkan menjadi $0,5 \mathrm{mg} / \mathrm{kgbb} /$ hari atau lebih rendah selama infeksi. ${ }^{17}$ Kasus yang berat memerlukan rawat inap dan diisolasi. Pasien dengan varisela memerlukan pemantauan terhadap kejadian komplikasi selama sakit hingga $7-10$ hari sesudahnya. ${ }^{16}$

Tabel 1.Tata laksana infeksi pada sindrom nefrotik sensitif steroid ${ }^{15}$

\begin{tabular}{llll}
\hline Infeksi & Jenis organisme yang umum & $\begin{array}{l}\text { Panduan antimikroba berdasarkan } \\
\text { Indian Academy of Pediatrics }\end{array}$ & $\begin{array}{l}\text { Panduan antimikroba } \\
\text { berdasarkan Royal Manchester } \\
\text { Children's Hospital, UK }\end{array}$ \\
\hline Peritonitis & $\begin{array}{l}\text { Streptococcus pneumonia, } \\
\text { Streptococcus pyogenes, Escherichia } \\
\text { coli }\end{array}$ & $\begin{array}{l}\text { Sefotaksim atau seftriakson } \\
7-10 \text { hari, ampisilin dan } \\
\text { aminoglikosida 7-10 hari }\end{array}$ & $\begin{array}{l}\text { Seftriakson (hindari } \\
\text { aminoglikosida karena } \\
\text { potensial toksik) }\end{array}$ \\
Pneumonia & $\begin{array}{l}\text { Streptococcus pneumonia, } \\
\text { Haemophylus influenzae, } \\
\text { Staphylococcus aureus }\end{array}$ & $\begin{array}{l}\text { Oral: amoksisilin, ko- } \\
\text { amoksiklav, eritromisin } \\
\text { Parenteral: ampisilin dan } \\
\text { aminoglikosida, atau sefotaksim/ } \\
\text { seftriakson 7-10 hari }\end{array}$ & $\begin{array}{l}\text { Ko-amoksiklav atau } \\
\text { klaritromisin (jika alergi } \\
\text { penisilin) }\end{array}$ \\
& $\begin{array}{l}\text { Kloksasilin dan seftriakson (7- } \\
\text { Jaringan lunak/selulitis }\end{array}$ & $\begin{array}{l}\text { Staphylococci, Streptoccoci grouploksasilin } \\
\text { A, Haemophylus influenza }\end{array}$ & Fluri), ko-amoksiklav \\
\hline
\end{tabular}


Terhadap sindrom nefrotik yang kontak dengan penderita campak, dapat dipertimbangkan pemberian imunoglobulin spesifik campak, sedangkan asiklovir tidak efektif.

Infeksi jamur dapat timbul pada saat terapi steroid. Infeksi kulit atau oral thrush karena jamur diterapi dengan flukonazol oral selama 10 hari $^{15}$

Sindrom nefrotik dengan uji tuberkulin positif memerlukan profilaksis antituberkulosis dengan isoniazid $5 \mathrm{mg} / \mathrm{kgbb} / \mathrm{hari}$ atau rifampisin $10 \mathrm{mg} / \mathrm{kgbb} /$ hari selama 6 bulan pada strain yang resisten. Sindrom nefrotik disertai tuberkulosis aktif memerlukan terapi antituberkulosis. ${ }^{11,16}$

Upaya mencegah infeksi dengan pemberian antibiotik profilaksis masih kontroversi. Meskipun ada yang menganggap bahwa antibiotik profilaksis perlu diberikan pada anak dengan risiko tinggi seperti umur $<2$ tahun, sindrom nefrotik resisten steroid dan relaps sering, dan anak yang pernah mengalami infeksi pneumokokus, namun pemberian antibiotk profilaksis bukan merupakan tindakan rutin atau standar pada sindrom nefrotik. ${ }^{8}$ Menurut American Academic of Pediatrics, tidak ada data yang mendukung efikasi penisilin profilaksis untuk mencegah peritonitis pada sindrom nefrotik idiopatik. ${ }^{18}$

\section{Hipertensi}

Hipertensi dapat terjadi saat awitan penyakit atau timbul sebagai efek samping pemberian steroid. ${ }^{16}$ American Academic of Pediatrics merekomendasikan tata laksana hipertensi berupa diit rendah garam, olahraga dan menurunkan berat badan jika terdapat obesitas. ${ }^{15}$ Antihipertensi yang sering digunakan pada anak adalah diuretik (furosemid, spironolakton, hidroklorotiazid), angiotensin converting enzyme inhibitors atau ACE inhibitors (kaptopril, lisinopril, enalapril), dan angiotensin receptor blockers atau $A R B$ (losartan, valsartan, irbesartan), calcium channel blockers, (amblodipin, nifedipin, isradipin), alpha-symphatetic agents (klonidin, prazosin), beta blockers (atenolol, metoprolol, labetalol), vasodilator (hidralazin, minoxidil). Jika tekanan darah melampaui persentil 90, dapat diberikan angioten converting enzyme inhibitors atau angiotensin receptor blockers. ${ }^{15}$ Angiotensin converting enzyme (ACE) inhibitor antara lain kaptopril (dosis 0,3-0,5 mg/kgbb/dosis diberikan 3 kali sehari, dengan dosis maksimum $6 \mathrm{mg} / \mathrm{kgbb} /$ hari) atau enalapril $(0,1-1,0 \mathrm{mg} / \mathrm{kgbb} / \mathrm{hari}$ dibagi 2 dosis, dosis $0,6 \mathrm{mg} / \mathrm{kgbb} /$ dosis atau maksimum 40 $\mathrm{mg} / \mathrm{hari}$ ) atau ramipril (dosis $0,05-2,0 \mathrm{mg} / \mathrm{kgbb} / \mathrm{hari}$ sekali sehari dengan dosis maksimum $10 \mathrm{mg}$ ), atau lisinopril (dosis $0,07 \mathrm{mg} / \mathrm{kgbb} /$ dosis hingga $5 \mathrm{mg} /$ dosis, dosis maksimal $40 \mathrm{mg} / \mathrm{hari}$ ), atau angiotensin receptor blocker seperti losartan 0,5-2,0 mg/kgbb/hari, dosis maksimum $100 \mathrm{mg} / \mathrm{hari}) .{ }^{13}$ Pada hipertensi persisten diperlukan penambahan obat antihipertensi lain seperti calcium channel blocker (amblodipin 0,1-0,6 mg/kgbb/ hari) atau vasodilator. Target penurunan tekanan darah ialah hingga persentil 75-90 berdasarkan umur, jenis kelamin, dan tinggi badan. ${ }^{13,15}$

\section{Antiproteinuria}

Pada sindrom nefrotik yang masih mengalami proteinuria seperti sindrom nefrotik relaps sering, dependen steroid, dan resisten steroid diperlukan pemberian obat antiproteinuria. Beberapa antihihipertensi telah terbukti mempunyai sifat antiproteinuria seperti angiotensin converting enzyme (ACE) inhibitor dan angiotensin II receptor blocker (ARB). Antihipertensi yang sering digunakan sebagai antiproteinuria antara lain kaptopril, enalapril, lisinopril, ramipril, dan losartan. ${ }^{13,15}$ Proteinuria diturunkan hingga minimal kurang dari proteinuria nefrotik, misalnya $<2 \mathrm{~g} / 1,73$ $\mathrm{m}^{2} /$ hari atau rasio protein/kreatinin $<0,2 \mathrm{~g} / \mathrm{mmol}$ dan meningkatkan albumin darah $>3,0 \mathrm{~g} / \mathrm{dL}$. Jika pasien tetap dalam keadaan nefrotik dan fungsi ginjal baik, dapat dipertimbangkan pemberian anti-inflamasi non steroid. ${ }^{13}$

\section{Tromboemboli}

Sindrom nefrotik merupakan predisposisi tromboemboli vena. Tromboemboli terjadi karena hilangnya antitrombin III, berkurangnya volume intravaskular (pemberian diuretik, diare dehidrasi), imobilisasi, kateter vaskular indwelling, dan pungsi vena dalam. Trombosis dicurigai pada sindrom nefrotik dengan oligoanuria, hematuria atau nyeri pinggang (trombosis vena renalis), kongesti vena, nyeri, berkurangnya mobilitas ekstremitas (trombosis vena dalam), atau kejang, muntah, defisit neurologis (trombosis vena kortikal dan sinus sagital). ${ }^{16}$

Hiperkoagulopati ditata laksana dengan pemberian 
aspirin 3-5 mg/kgbb/hari (dosis maksimum $100 \mathrm{mg}$ per hari) atau obat anti-platetelet seperti dipiridamol 1-2 mg/kgbb (maksimum $100 \mathrm{mg}$ ) setiap 8 jam, ${ }^{13,15}$ atau antikoagulan heparin intravena atau heparin berat molekul rendah seperti enoxaparin dengan dosis permulaan $1 \mathrm{mg} / \mathrm{kgbb}$ setiap 12 jam yang diberikan subkutan sebagai terapi awal dan dilanjutkan dengan antikoagulan oral jangka lama, selama 6 bulan atau lebih. ${ }^{9,10,13,16}$

Upaya mencegah komplikasi tromboemboli dapat dilakukan dengan ambulasi regular, menghindari hemokonsentrasi akibat hipovolume, menghindari pemakaian kateter vena sentral, dan terapi awal sepsis dan hipovolume. ${ }^{10}$ American Academic of Pediatrics merekomendasikan anak tetap beraktifitas selama periode aktif dan risiko tromboemboli yang meningkat, dan hindari tirah baring jangka lama. ${ }^{18}$

Belum ada penelitian controlled trial mengenai efektivitas dan keamanan pemberian antikoagulasi profilaksis untuk mencegah tromboemboli pada anak dengan sindrom nefrotik. ${ }^{10}$ Menurut Indian Pediatric Society, tidak ada peran pemberian profilaksis dengan antikoagulan pada sindrom nefrotik idiopatik, bahkan pada keadaan hipoalbuminemia dan edema sekalipun. ${ }^{17}$ Dalam panduan di Perancis, tidak ada konsensus tentang pemberian profilaksis untuk tromboemboli, namun pada anak dengan keadaan berat (albumin $<2,0 \mathrm{~g} / \mathrm{dL}$, fibrinogen $>6 \mathrm{~g} / \mathrm{L}$, antitrombin III $<70 \%$, D-dimer $>1.000 \mathrm{ng} / \mathrm{mL}$ ) dapat dipertimbangkan pemberian aspirin atau heparin berat molekul rendah sebagai profilaksis. ${ }^{10,19}$ Oleh sebab itu, pemberian profilaksis dengan antikoagulan tidak dianjurkan pada sindrom nefrotik. ${ }^{9,16}$

\section{Hiperlipidemia dan penyakit kardiovaskular}

Hiperlipidemia persisten atau kronik merupakan faktor risiko penyakit kardiovaskular dan kerusakan glomerulus progresif yang berperan terhadap progresivitas gagal ginjal kronik. ${ }^{10,16}$ Hiperlipidemia ditandai peningkatan kolesterol total, trigliserida, low density lipoprotein ( $L D L)$, very low density lipoprotein (VLDL), sedangkan kadar cardioprotective high density lipoprotein (HDL) normal atau menurun. Terdapat juga peningkatan lipoprotein A yang bersifat aterogenik dan trombogenik. Hiperlipidemia terjadi karena meningkatnya aktivitas hepatic-3hydroxy-3- methylglutaryl-coenzyme $A$ (HMG-CoA) reductase dan acyl-coenzyme-A-cholesterol acyltransferase atau penurunan aktivitas lipoprotein lipase. ${ }^{15}$

Pada sindrom nefrotik sentitif steroid, hiperlipidemia bersifat sementara dan akan menurun seiring dengan remisi, biasanya tidak menyebabkan komplikasi dan tidak memerlukan obat penurun lemak, cukup dengan diit rendah lemak. Pada sindrom nefrotik resisten steroid, sering terjadi hiperlipidemia dengan berbagai risiko, sehingga selain diit rendah lemak jenuh, dapat dipertimbangkan pemberian obat penurun lemak seperti inhibitor HMG-coA reduktase (statin: simvastatin, atorvastatin, lovastatin) $8,11,15,16$ dan probucol. ${ }^{8,9,15}$ Pemberian inhibitor HMG CoA reduktase direkomendasikan jika ditemukan kelainan biokimiawi yang menetap selama 3-6 bulan, yakni kolesterol total $>200 \mathrm{mg} / \mathrm{dL}$, kolesterol LDL $>130$ $\mathrm{mg} / \mathrm{dL}$, trigliserida $>100 \mathrm{mg} / \mathrm{dL} .{ }^{16}$ Obat inhibitor $H M G$ CoA reductase antara lain lovastatin 0,4-0,8 $\mathrm{mg} / \mathrm{kgbb}$ malam hari dan dosis dapat dinaikkan setiap bulan dengan dosis maksimum $40 \mathrm{mg} / 12 \mathrm{jam}$. Atorvastatin 10-20 mg per hari untuk anak $>5$ tahun. atau $0,2-1,6 \mathrm{mg} / \mathrm{kgbb}$ malam hari dan dosis dapat dinaikkan setiap bulannya hingga dosis maksimum $80 \mathrm{mg}$ setiap malam. Simvastatin mempunyai risiko tinggi rabdomiolisis. ${ }^{13}$ Penelitian membuktikan bahwa dalam waktu 2-4 bulan setelah pemberian inhibitor $H M G-C o A$ reductase terdapat penurunan kolesterol total 40\%, kolesterol LDL 44\%, trigliserida 33\%, namun tidak ada perubahan kadar kolesterol HDL. ${ }^{8,10}$

Modifikasi diit potensial menurunkan risiko penyakit kardiovaskular. American Academic of Pediatrics merekomendasikan diit rendah lemak pada anak dengan sindrom nefrotik idiopatik. ${ }^{18}$ Diit vegan, rendah protein, dan vegetarian dapat menurunkan kadar kolesterol tetapi tidak punya efek terhadap trigliserida. ${ }^{15}$

\section{Imunisasi}

Pada anak dengan sindrom nefrotik, idealnya vaksinasi dilakukan sebelum mendapat terapi imunosupresan. ${ }^{15}$ Pada sindrom nefrotik, vaksinasi dapat mencetuskan relaps meskipun risikonya kecil dan sangat jarang. ${ }^{11,12}$

Imunisasi dengan vaksin virus hidup seperti polio oral, campak, MMR, dan varisela tidak direkomendasikan untuk pasien yang sedang mendapat prednison $2 \mathrm{mg} / \mathrm{kgbb} / \mathrm{hari}$ atau lebih dari 14 hari. ${ }^{8}$ Vaksin 
hidup dapat diberikan pada pasien yang tidak mendapat imunosupresan atau steroid selama 6 minggu atau lebih.Jika sangat diperlukan, vaksin hidup dapat diberikan pada sindrom nefrotik dengan prednison dosis $<0,5 \mathrm{mg} / \mathrm{kgbb} /$ hari secara alternating. ${ }^{11,12}$

Pada sindrom nefrotik, dapat diberikan vaksin polio suntik. Jika anak sudah mendapat imunisasi primer dengan vaksin polio oral (6 minggu, 10 minggu, 14 minggu), dapat diberikan vaksin polio suntik dua dosis dengan interval 2 bulan diikuti dengan dosis ketiga 6 bulan setelah dosis pertama dan booster pada umur 5 tahun. ${ }^{16}$

Pasien yang belum mendapat imunisasi campak perlu mendapat profilaksis dengan imunoglobulin jika terpapar dengan penderita campak. ${ }^{12}$

Anak penderita sindrom nefrotik dianjurkan memperoleh imunisasi varisela. Vaksinasi varisela aman dan efektif pada anak dalam keadaan remisi, bahkan pada keadaan mendapat steroid dosis rendah selang hari. ${ }^{10}$ American Academic of Pediatrics merekomendasikan vaksinasi varisela untuk anak dengan sindrom nefrotik idiopatik yang non-imun. ${ }^{18}$ Pada sindrom nefrotik keadaan remisi dan tidak mendapat obat imunosupresan atau steroid ditapering off, vaksin varisela diberikan 2 dosis dengan interval 4 minggu. ${ }^{16}$ Penelitian di Turki terhadap anak dengan sindrom nefrotik sensitif steroid remisi atau telah berhenti mengkonsumsi kortikosteroid minimal 6 minggu sebelum vaksinasi menunjukkan bahwa $85 \%$ mengalami serokonversi setelah 8 minggu vaksinasi dibandingkan dengan $86 \%$ pada anak normal. Dua tahun kemudian, antibodi varisela-zoster masih terdeteksi pada 70\% anak dengan sindrom nefrotik idiopatik dan pada 59\% anak normal. Direkomendasikan pemberian vaksin varisela minimal 3 bulan setelah terapi kortikosteroid dosis tinggi dihentikan. ${ }^{15}$

Anak dengan sindrom nefrotik idiopatik merupakan risiko tinggi untuk infeksi virus influenza dan dapat mengalami komplikasi berat. ${ }^{5}$ American Academic of Pediatrics merekomendasikan pemberian imunisasi influenza setiap tahun untuk anak sindrom nefrotik idiopatik. ${ }^{18}$ Ada dua jenis vaksin influenza yakni inactivated intramuscular vaccine dan live attenuated intranasal vaccine. Vaksin hidup intranasal diindikasi kontra untuk anak yang mendapat terapi kortikosteroid. ${ }^{15}$

Imunisasi terhadap Pneumococus direkomendasikan dan terbukti efektif pada sindrom nefrotik dalam keadaan remisi. Imunisasi terhadap Pneumococcus juga efektif meski vaksinasi dilakukan pada saat anak mendapat steroid, namun pada pemantauan hingga 36 bulan, terdapat penurunan antibodi terhadap Pneumococcus setelah pemberian vaksinasi pneumococcal polyvalent. ${ }^{8}$ Indian Academic of Pediatrics dan American Academic of Pediatrics merekomendasikan pemberian vaksin pneumokokus pada sindrom nefrotik idiopatik. Vaksinasi pneumokokus direkomendasikan untuk semua anak dengan sindrom nefrotik berumur lebih dari 2 tahun, selama remisi dan lebih baik ketika pasien tidak mendapat steroid. Imunisasi booster diberikan setiap 5 tahun terhadap pasien yang mendapat vaksinasi inisial sebelum berumur 5 tahun dan masih mengalami relaps. ${ }^{14}$

\section{Kalsium dan suplementasi vitamin D}

Pada sindrom nefrotik dapat terjadi hipokalsemia akibat penurunan 25-hidroksi-kalsiferol karena keluarnya vitamin-D-binding-protein melalui urin, serta penggunaan steroid jangka panjang yang menyebabkan osteoporosis dan osteopenia. ${ }^{11,15,16}$ Vitamin-D binding protein sebagai bagian terbanyak 25-hidroksikolekalsiferol keluar melalui urin menyebabkan kadar 1,25-dihidroksi-kolekalsiferol D3 serum menurun, yang menimbulkan hiperparatiroidisme sekunder. Suplementasi vitamin D diberikan pada pasien yang tidak remisi atau yang menjadi penyakit ginjal kronik, hiperparatiroidisme, atau hipokalsemia bermakna persisten. ${ }^{8}$

Pemberian steroid jangka lama dapat menyebabkan penurunan bone-formation yang terlihat dengan perubahan kadar osteokalsin dan fosfatase alkali serta kadar 25 hidroksi-D yang rendah. ${ }^{10}$ Kortikosteroid menyebabkan peningkatan resorbsi tulang melalui aktivitas osteoklast pada tulang dan penurunan pembentukan tulang dengan menurunkan jumlah dan fungsi osteoblast. ${ }^{8}$ Osteoporosis yang diinduksi steroid dapat dicegah dengan bifosfonat, dan suplementasi vitamin D. ${ }^{16}$ Indian Pediatric Society merekomendasikan pemberian kalsium dan vitamin D kepada anak dengan sindrom nefrotik idiopatik yang mendapat kortikosteroid jangka lama ( $>3$ bulan) dengan dosis kalsium 250-500 mg/hari dan vitamin D 125-250 IU/ hari. ${ }^{717}$ Bila timbul tetani akibat hipokalsemia, dapat diberikan kalsium glukonas $10 \%$ dengan dosis $0,5 \mathrm{~mL} /$ kgbb intravena perlahan-lahan. ${ }^{11}$ 


\section{Anemia dan defisiensi elektrolit}

Sindrom nefrotik yang berlangsung lama dapat menyebabkan anemia karena kehilangan eritropoietin dan transferin melalui urin. Anemia dapat juga disebabkan kombinasi penurunan waktu paruh eritropoietin serum dan peningkatan katabolisme transferin yang mengakibatkan erythropoietin-responsive anemia atau anemia defisiensi besi. Meskipun pemberian eritropoietin dapat memulihkan anemia, namun terapi menginduksi remisi merupakan upaya yang paling efektif untuk mengatasi anemia. ${ }^{8}$

Defisiensi tembaga (cuprum) dan zink dapat ditemukan pada sindrom nefrotik. Defisiensi tembaga terjadi karena pengeluaran seruloplasmin melalui urin sedangkan defisiensi zink terjadi karena pengeluaran zink terikat dengan albumin melalui urin. Defisiensi zat ini berkaitan dengan kelainan imunologis dan pertumbuhan. ${ }^{8}$

\section{Kelainan tiroid}

Kehilangan hormon melalui urin pada sindrom nefrotik dapat menyebabkan kelainan endokrin. Pada sindrom nefrotik terjadi pengeluaran thyroxinebinding-globulin melalui urin menyebabkan kadar T4 dan T3 rendah, namun kadar free thyroxine (FT4) dan thyroid stimulating hormone (TSH) serum biasanya normal (euthyroid), sehingga tidak menimbulkan manifestasi klinis hipotiroidisme dan dikenal dengan hipotiroidisme ringan/subkilinik. Keadaan seperti ini tidak memerlukan terapi karena akan menjadi normal setelah remisi. Hipotiroidisme lebih sering terjadi pada sindrom nefrotik resisten steroid dibandingkan dengan sindrom nefrotik sensitif steroid. ${ }^{10,15}$ Pada sindrom nefrotik kongenital dapat ditemukan manifestasi klinis hipotiroid berat yang memerlukan terapi levotiroksin. ${ }^{8}$ Direkomendasikan memeriksa kadar hormon tiroid jika terdapat proteinuria berat yang menetap $>3$ minggu. ${ }^{15}$

\section{Aktivitas fisik}

Pada sindrom nefrotik, aktivitas fisik tidak perlu dibatasi, tirah baring tidak perlu dipaksakan. Aktivitas fisik akan disesuaikan dengan kemampuan pasien. Anak dengan edema ringan atau tidak berat tidak perlu dilarang pergi ke sekolah. ${ }^{6,11}$

\section{Efek samping terapi}

Pemberian kortikosteroid jangka lama akan menimbulkan berbagai efek samping antara lain retensi air dan garam, hipertensi, perubahan tingkah laku, meningkatnya risiko infeksi, cushingoid, demineralisasi tulang, gangguan pertumbuhan, katarak, nafsu makan yang meningkat, dan lain sebagainya. Imunosupresan non steroid dapat menimbulkan berbagai efek samping seperti gangguan saluran cerna, depresi sumsum tulang, rambut rontok, ginggiva menebal, atau penurunan fungsi ginjal. Hal ini perlu dijelaskan kepada pasien atau orangtua. Perlu dilakukan pemantauan efek samping obat di samping perjalanan penyakit, meliputi pengukuran tekanan darah, berat badan, tinggi badan, atau tanda-tanda efek samping lainnya. Efek samping memerlukan tata laksana sesuai dengan manifestasi klinis yang timbul. ${ }^{11}$

\section{Pertumbuhan dan obesitas}

Efek samping jangka lama pemberian kortikosteroid pada sindrom nefrotik adalah gangguan pertumbuhan dan obesitas. ${ }^{15}$ Meskipun mekanisme hambatan pertumbuhan terutama pada anak yang memperoleh kortikosteroid belum semuanya dimengerti, tetapi diketahui terdapat peran kortikosteroid terhadap fungsi kondrosit. Kortikosteroid menurunkan produksi osteoblast dan meningkatkan aktivitas osteoklast sehingga terjadi osteopenia. Kortikosteroid akan menghambat aktivitas somatomedin dan menyebabkan efek inhibitor terhadap metabolisme kolagen yang memengaruhi pertumbuhan tulang. Dilaporkan bahwa kadar insulin like-growth factor-1 (IGF-1) dan IGF-2 pada sindrom nefrotik rendah. Pengaruh kortikosteroid terhadap pertumbuhan atau tinggi badan sangat kecil jika diberikan dengan dosis selang hari. Pada remaja, dapat terjadi pubertas terlambat dan gagal tumbuh. Pada sindrom nefrotik yang mendapat kortikosteroid, kadar growth hormone dan sekresi gonadotropin menurun dan akan kembali normal setelah penghentian kortikosteroid. Hal ini kemungkinan disebabkan pengaruh disfungsi hipotalamus-pituitari terhadap retardasi pertumbuhan. ${ }^{6}$ Diperlukan pemantauan pertumbuhan linier dan indeks massa tubuh pada anak dengan sindrom nefrotik idiopatik yang diperlukan untuk konsultasi diit yang sesuai. ${ }^{15}$ 
Sudung O. Pardede: Tata laksana non imunosupresan sindrom nefrotik

\section{Stres steroid (insufisiensi adrenal)}

Pasien yang pernah mendapat steroid dosis tinggi lebih dari 2 minggu pada tahun sebelumnya mempunyai risiko mengalami supresi aksis hipotalamus pituitaryadrenal, dan dipertimbangkan untuk medapat suplemen steroid selama pembedahan, anestesi, dan infeksi serius. ${ }^{16}$ Indian Pediatric Society merekomendasikan bahwa anak yang mendapat kortikosteroid dosis tinggi (prednisolon $2 \mathrm{mg} / \mathrm{kgbb} /$ hari selama $1 \mathrm{minggu}$ atau lebih, atau prednisolon $1 \mathrm{mg} / \mathrm{kgbb} /$ hari selama 1 bulan atau lebih) dalam 2 tahun belakangan memerlukan suplementasi kortikosteroid jika terjadi infeksi serius, ${ }^{17}$ tetapi panduan Pediatric Endocrine Society menyebutkan bahwa infeksi virus yang tidak kompleks seperti infeksi saluran nafas atas dengan nyeri tenggorokan, rinorhea, otitis media, atau demam derajat rendah tidak memerlukan terapi steroid. ${ }^{15}$

\section{Edukasi dan konseling}

Sindrom nefrotik merupakan penyakit ginjal yang sering pada anak, bersifat kronik, dapat mengalami relaps hingga berkali-kali atau menjadi dependen steroid atau resisten steroid, sehingga memerlukan pemantauan jangka lama. Kepada pasien dan orangtua perlu dijelaskan tentang sindrom nefrotik dan perjalanan penyakit, penyebab, komplikasi, tata laksana, maupun luaran penyakit. Pasien perlu kontrol teratur untuk evaluasi pasien dan perlu dibuat catatan tentang diet, hasil pemeriksaan urin, pemberian obat, penyakit yang timbul di antara relaps, perjalanan penyakit termasuk nilai ambang steroid pada saat relaps. ${ }^{16}$

Anak dapat mengalami berbagai jenis pemeriksaan penunjang seperti pemeriksaan laboratorium, pencitraan, bahkan biopsi ginjal. Keadaan ini menyebabkan anak ketakutan, kehidupan anak terganggu karena aktivitas terbatas, kegiatan di sekolah terpengaruh karena anak sering tidak masuk sekolah, kegiatan sehari-hari dan kegiatan lainnya terganggu yang membuat anak mengalami beban psikologis. Selain anak, orangtua juga mengalami beban karena tenaga dan waktu yang tersita untuk mengantar anak berobat, memerlukan perhatian lebih, serta masalah biaya yang akan memengaruhi psikologis keluarga. Oleh karena itu, pendekatan psikologis sangat diperlukan baik kepada anak maupun orangtua atau keluarga. ${ }^{20}$

\section{Penutup}

Terapi utama sindom nefrotik pada anak adalah kortikosteroid, namun terapi suportif sangat penting untuk mengatasi manifestasi klinis maupun komplikasi sindrom nefrotik. Selain itu, efek samping pemberian obat juga perlu mendapat perhatian.

\section{Daftar pustaka}

1. Lombel RM, Hodson EM, Gipson DS. Treatment of steroidresistant nephrotic syndrome in children: new guidelines from KDIGO. Pediatr Nephrol 2013:28:409-14.

2. Clark AG, Barrat TM. Steroid responsive nephrotic syndrome. Dalam: Barrat TM, Avner ED, Harmon WE, penyunting. Pediatric Nephrology. Edisi ke-4. Baltimore: Lippincott Williams \& Wilkins;1999. h.731-47.

3. Gbadegesin R, Smoyer WE. Nephrotic syndrome. Dalam: Geary D, Schaefer F, penyunting. Comprehensive Pediatric Nephrology. Edisi Pertama. Philadelphia: Mosby Elsevier; 2008.h.1205-18.

4. Haycock GB. Steroid responsive nephrotic syndrome. Dalam: Postlethwaite RJ, penyunting. Clinical Paediatric Nephrology. Edisi 2. Oxford: Butterworth-Heinemann; 1994.h.210-25.

5. Haycock GB. The child with idiopathic nephrotic syndrome. Dalam: Postlethwaite RJ, Webb N, penyunting. Clinical Paediatric Nephrology. Edisi ke-3. New York: Exford University Press;2003.h.341-66.

6. Kher KK. Nephrotic syndrome. Dalam: Kher KK, Makker SP, penyunting. Clinical Pediatric Nephrology. New York: McGraw-Hill Inc; 1992.h.137-74.

7. Bagga A, Sinha A, Gulati A. Steroid resistant nephrotic syndrome. Dalam: Protocols in Pediatric Nephrology. Edisi ke1, New Delhi, CBS Publishers \& Distributors;2012,h.97-104.

8. Valentini RP, Smoyer WE. Nephrotic syndrome. Dalam: Kher KK, Schnaper HW, Makker SP. Clinical pediatric nephrology, Edisi kedua. London: Informa Healthcare;2007.h.155-94.

9. Lee EKW, Chan WKY, Lai WM, Chiu MC. Nephrotic syndrome: Long term management. Dalam: Chiu MC, Yap HK, penyunting. Practical Paediatric Nephrology. Edisi pertama. Hong Kong: Medcom Limited;2005.h.116-29.

10. Niaudet P, Boyer O. Idiopathic nephrotic syndrome in children: Clinical aspects. Dalam: Avner ED, Harmon WE, Niaudet P, Yoshikawa N, Emma F, Goldstein SL, penyunting. Pediatric Nephrology. Edisi ketujuh. New York: Springer Reference;2016.h.839-82.

11. Trihono PP, Alatas H, Tambunan T. Pardede SO. Konsensus tata laksana sindrom nefrotik idiopatik pada anak. UKK 
Nefrologi IDAI, Edisi kedua, Jakarta: Badan Penerbit IDAI; 2008.h.1-22.

12. Bagga A, Menon S. Idiopathic nephrotic syndrome: Initial management. Dalam: Chiu MC, Yap HK, penyunting. Practical Paediatric Nephrology. Edisi pertama. Hong Kong: Medcom Limited;2005.h.109-15.

13. Yap HK, Aragon ET, Resontoc LPR, Yeo WS. Childhood nephrotic syndrome. Dalam: Yap HK, Liu ID, Ng KH, penyunting, Pediatric Nephrology: On the go. Edisi ke-2, Singapore: Children's Kidney Centre;2015.h.213-27.

14. Bagga A, Mantan M. Nephrotic syndrome in children. Indian J Med Res 2005;122:13-28.

15. McCaffrey J, Lennon R, Webb NJA. The non-immunosuppressive management of childhood nephrotic syndrome. Pediatr Nephrol 2016;31:1383-402.

16. Bagga A, Sinha A, Gulati A. Supportive care in nephrotic syndrome. Dalam: Protocols in Pediatric Nephrology. Edisi ke1. New Delhi: CBS Publishers \& Distributors;2012.h.105-9.

17. Bagga A, Ali U, Nanarjee S, Kanitkar M, Padke KD, Senguttuvan $\mathrm{p}$, dkk. Indian Pediatric Nephrologyy Group, Indian Academic of Pediatrics. Management of steroid sensitive nephrotic syndrome.: revised guidelines. Indian Pediatr 2008;45:203-14.

18. Gipson DS, Massengill SF, Yao L, Nagaraj S, Smoyer WE, Mahan DJ, dkk. Management of childhood onset nephrotic syndrome. Pediatrics 2009;124:747-57.

19. Resh M, Mahmoodi BK, Navis GJ, Veeger NJ, Lijfering WM. Statin use in patients with nephrotic syndrome is associated with a lower risk of venous thromboembolism. Thromb Res 2011;127:395-9.

20. Mitra S, Banarjee $S$. The impact of pediatric nephrotic syndrome on families. Pediatr Nephrol 20011;26:1235-40. 